\title{
Testing the application of an automatic milking system on buffalo (Bubalus bubalis)
}

\author{
Salvatore Faugno, ${ }^{1}$ Stefania Pindozzi, ${ }^{1}$ Collins Okello, ${ }^{2}$ Maura Sannino ${ }^{1,3}$ \\ ${ }^{1}$ Department of Agriculture, University of Naples Federico II, Portici (NA), Italy; \\ ${ }^{2}$ Department of Biosystem Engineering, Gulu University, Gulu, Uganda; \\ ${ }^{3}$ Department of Agriculture, Forest, Nature and Energy, Tuscia University, Viterbo, Italy
}

\begin{abstract}
The automatic milking systems (AMS) have been deeply studied in dairy cows applications, but not in the case of buffaloes; although, a few applications to the species can be found in literature. The objective of this study is to compare some important functional aspects of AMS with the conventional milking systems. Aspects such as adaptation of buffalo to AMS and the possible relationship between milking frequency and daily milk yield were evaluated. Two groups of Bubalus bubalis were reared in the same barn, in a farm located in Piana del Sele (SA) southern Italy. Fourty primiparous buffaloes were milked using an AMS, and at the same time another herd of 40 were milked twice a day using traditional milking system (tandem). The adaptation period of buffaloes to AMS was 2 months. Milking frequency with the AMS was significantly higher compared to the one of traditional methods ( $2.3 \pm 0.17$ times/d $v s 2$ times/d). Daily milk yield with the AMS was observed to be significantly higher than with traditional milking system $(7.9 \pm 1.3 \mathrm{~kg} / \mathrm{d}$ vs $6.9 \pm 1.06 \mathrm{~kg} / \mathrm{d})$. In this study, there was no significant relationship between the increase of daily milking frequency and daily milk yield. We can conclude that a positive AMS effect on daily milk yield and milking frequency is possible and so we can expect successful applications of the AMS to dairy buffalo farms.
\end{abstract}

Correspondence: Maura Sannino, Department of Agriculture, University of Naples Federico II, via Università 100, 80055 Portici (NA), Italy.

Tel.: +39.0812539148.

E-mail: maura.sannino@unina.it

Key words: Automatic milking, buffalo, milking frequency, milk yield.

Acknowledgments: the authors would like to express their gratitude to Dr. Antonio Palmieri who gave the possibility of carrying out the research activities in his buffalo farm.

Received for publication: 8 September 2014.

Accepted for publication: 8 January 2015.

(C) Copyright S. Faugno et al., 2015

Licensee PAGEPress, Italy

Journal of Agricultural Engineering 2015; XLVI:437

doi:10.4081/jae.2015.437

This article is distributed under the terms of the Creative Commons Attribution Noncommercial License (by-nc 3.0) which permits any noncommercial use, distribution, and reproduction in any medium, provided the original author(s) and source are credited.

\section{Introduction}

The first automatic milking system (AMS) was introduced in a commercial dairy farm in the Netherlands in 1992. Since then, the number of dairy enterprises with AMS grew quickly (Svennersten-Sjaunja and Pettersson, 2008). By the end of 2009, De Koning (2010) estimated that there were about 8000 commercial dairies using robotic milking stalls to milk their cows. The use of milking robot in Italy is mainly concentrated in the northern and central Italy, though a few units have also been installed in southern Italy, especially in Campania region where there is a greater number of herds of buffalo than dairy cows.

The motivations for installing an AMS can be diverse; Bijl et al. (2007) showed that farms with an AMS used 29\% less labour than farms with conventional milking systems. The success of robotic milking depends on the cow's willingness to voluntarily visit the robotic milking stall at a satisfactory frequency to support economic milk production without incurring in extra working costs (Hogeveen et al., 2001; Svennersten-Sjaunja and Pettersson, 2008; Jacobs and Siegford, 2012). Several authors have investigated the effects of milking frequency on the milk yield. It was previously reported that milk yield and flow rate, are dependent on the milking interval (Hogeveen et al., 2001). For cows, an increase in milk yields from 6 to $25 \%$ in complete lactations, has been observed when milking frequency is increased from two to three times per day (Amos et al., 1985; Stelwagen et al., 2013; Wright et al., 2013). Various authors observed that in cows milked more than twice per day in AMS, there was a production increase of $12 \%$ compared to cows milked twice per day in the conventional system (De Koning et al., 2002; Wagner-Storch and Palmer, 2003; Wade et al., 2004); other researches did not noticed a relationship between the increase of daily milking frequency in AMS and the daily milk yield (Erdman and Varner, 1994; Albeni et al., 2005; Speroni et al., 2006; Gygax et al., 2007).

An increase of production in AMS could be also caused by several factors. According to Hopster et al. (2002) the main cause is the less physiological stress as response of cows during AMS milking. Knight and Wilde (1993) and Løvendahl and Madsen (2001) showed the AMS production increase is caused by lactations persistence with a more stable production until the end of the lactation.

Typical livestock husbandry in Campania region of southern Italy is the raring of buffalo (Bubalus bubalis), with more than 260,000 heads under production (Pindozzi et al., 2013). The buffalo raring is the most important agricultural activity of the region and one of the fundamental contributors to the gross domestic product of Campania region (Infascelli et al., 2010). Currently, buffaloes are not so well known and studied in the rest of Europe as in Campania. For some characteristics, they are similar to cows (Bos taurus) but the physical aspects, behaviour and the milk production are strongly different. They are more sullen and irritable than milk cows and generally the daily milk yield of buffaloes is about $12 \mathrm{~L}$; that is about a third of the yield of the cows 
(Zicarelli, 2001). Studies lead in other countries showed that buffaloes are a hard-to-milking species than cows; this is due to a delay in milk ejection caused by a different udder anatomy, which presents longer and thicker nipples (Thomas et al., 2004; Borghese et al., 2007; Ambord et al., 2010). The reduced milk production and behaviour of buffalos is influencing companies in the industry to introduce the robotic milking system. AMS are deeply studied in dairy cows applications, but not yet deeply studied on buffalos, though a few applications to the species can be found in literature (Faugno et al., 2009; Tangorra et al., 2010; Caria et al., 2014).

The aim of this paper is to evaluate the effect of introducing an AMS in a large buffalo farm. Thus, a literature gap can be found about the use of AMS in this kind of livestock. The first application of robotized milking was implemented in 2008 in the south of Italy at a place called Piana del Sele (SA). The objective of this study is to evaluate some important functional aspects of AMS such as Buffalo adaptation to AMS, the milking frequency, the daily milk yield and a possible relationship between them.

\section{Materials and methods}

\section{Farm and housing description}

The study was carried out in the farm Vannulo. The farm occupies a land area of about 200 hectares, and to the best of our knowledge it is the only farm in the world that introduced the AMS in the case of buffaloes. During the study period, there were two types of milking-stables in use at the farm. The first and oldest one is a loose-housing stall and was occupied by 230 buffaloes of which 190 were lactating and the remaining 40 were dry animals. The tandem $(5+5)$ milking system was used in this stall.

The second milking-stable is new and it was constructed with the introduction of automatic milking system. The layout of this stall is shown in Figure 1. The entire surface was divided in four sectors, each of them with $40 \times 32 \mathrm{~m}$ dimensions. Each sector was provided with a DeLaval AMS VMS 2007 (DeLaval, Tumba, Sweden) model, installed, which could accommodate 66 buffaloes (Caria et al., 2014).

Buffalos were fed on total mixed rotation (TMR) based on corn (18\%) and grass silage (24\%), and was distributed once a day (07.30 to $09.00 \mathrm{~h}$ ). Furthermore, different amounts of commercial concentrates were administered, ranging from 4 to $6 \mathrm{~kg} / \mathrm{d}$ per buffalo. These were served in equal amount in both systems, AMS and tandem. In AMS, concentrates were served during milking operations while, in tandem, concentrates were mixed in feed ration.

\section{Data collection}

Data were collected over two different time periods from November 2008 to December 2010 and from January 2013 to May 2014. Data were collected in 4 AMS (VMS, DeLaval). The machine's working parameters

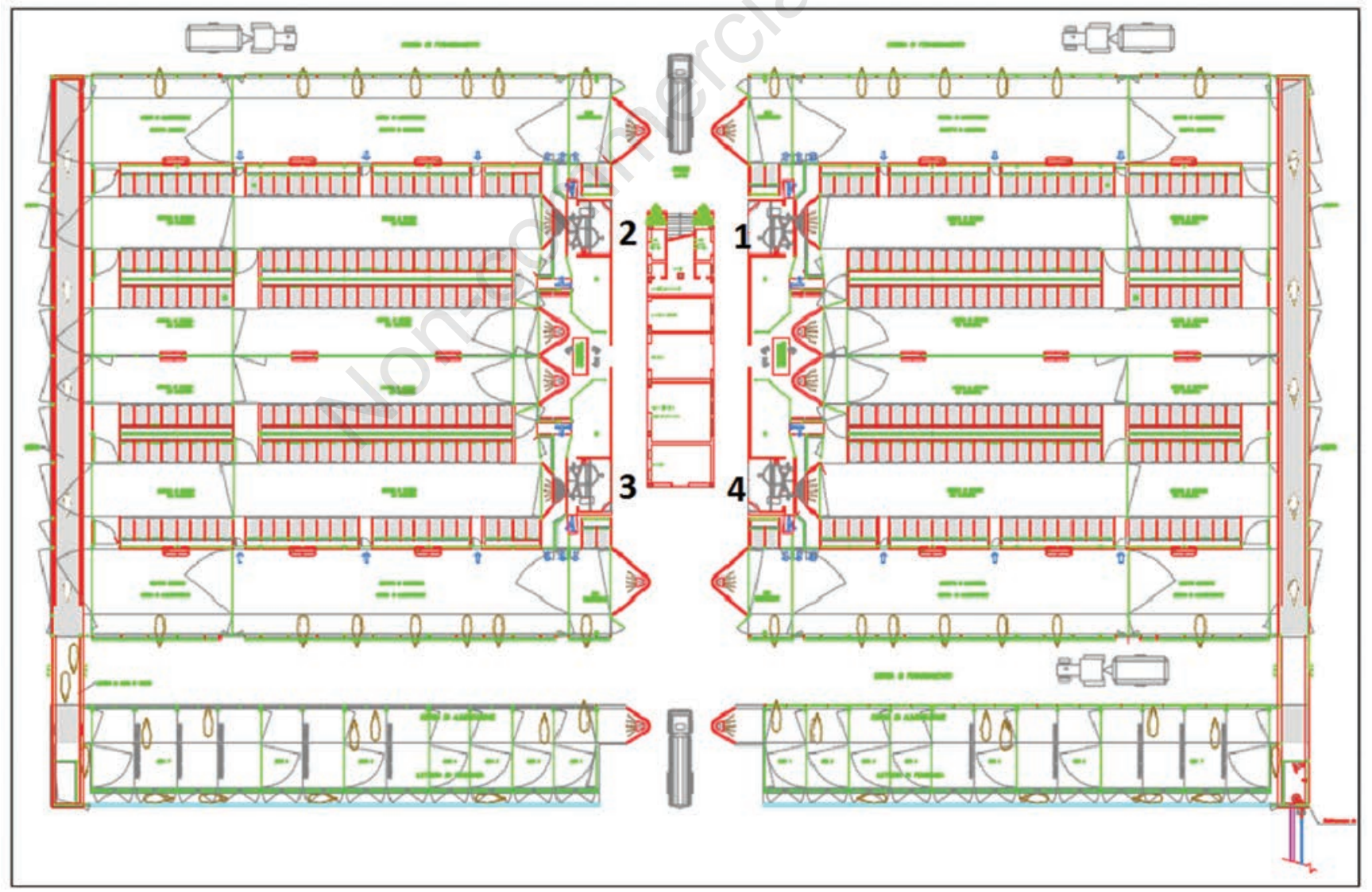

Figure 1. Farm layout was divided in four sectors, each with a floor dimension of $40 \times 32 \mathrm{~m}$, and each with a DeLaval automatic milking system model VMS 2007 installed. 
recorded by the management software (DeLaval, DelPro, DeLaval) were $42 \mathrm{kPa}$ vacuum, 60 cycles/min pulsator rate, and $60 \%$ pulsator ratio. The study was divided in two phases, the first involved the adaptation of buffaloes to the new automatic milking system and the second was a comparison of performance between traditional milking-room (tandem) and the automatic milking system.

The initial phase of the study, from November 2008 to December 2010 , involved an evaluation of the adaptation of animals to four AMS installed in the farm. The analysis was carried out by observing the behavioural aspects of both primiparous and multiparous buffaloes during the approach phase and/or of starting of AMS.

In accordance with Faugno et al. (2009) buffaloes were selected with more peacefully behavioural profiles, in order to avoid damages to the robot and injuries to the animals themselves. Another criterion was to ensure regular morphology of the udder with teats disposed within the range of action of robot arm. Out of 190 buffaloes present in the herd, 168 buffaloes (Table 1) were selected as eligible to AMS according to similar physical and behavioural characteristics. The chosen animals were introduced to robotic milking gradually.

The milking frequency was used as an indicator of the achieved adaptation of the animal to the AMS. Thus, the phase of animals' adaptation was considered complete when the observed daily milking frequency, two times per day, was the same as the traditional mechanical milking machine. During the first phase of analysis, the daily milking distribution was considered to be important, since its concentration during specific times of the day influences the capacity of the AMS. Such a concentration would lead to a reduction of waiting stress, which is one of the benefits of the new technology.

The second phase of the study, from January 2013 to May 2014, was concerned with the analysis of milk yield. The study was carried out on two groups of 40 primiparous buffaloes each; this technique was inspired by Albeni et al. (2005) and Speroni et al. (2006) researches but with a different animals' number. 80 primiparous buffaloes were selected randomly within primiparous of the herd which were similar in age, physical characteristics (regular udder), diet, milked in the same period, in the same concern and, so, in the same environmental conditions. The first set was subjected to milking using the AMS and the second to the traditional milking system. During the study, number of collar, number of milking per day, milk yield per lactation and daily milk yield for each buffalo were recorded. Data from the first group were automatically collected by the management DeLaval software incorporated in AMS. Data from the second group were collected physically, on a daily basis by the company staff.

Table 1. Descriptive data of buffaloes during the experimental period (November 2008 to December 2010).

\begin{tabular}{|c|c|c|c|c|}
\hline Variable & AMS1 & AMS2 & AMS3 & AMS4 \\
\hline Buffalo per AMS (no.) & 42 & 42 & 42 & 42 \\
\hline Lactation stage & 2 & 2 & 3 & 1 \\
\hline Hours from calving (h) & $11.12 \pm 0.75$ & $11.20 \pm 0.85$ & $10.88 \pm 0.82$ & $11 \pm 0.72$ \\
\hline Milk yield (kg/milking) & $2.6 \pm 0.8$ & $2.5 \pm 1.0$ & $2.8 \pm 1.3$ & $2.5 \pm 1.2$ \\
\hline Average milk flow rate (kg/min) & $1.3 \pm 0.6$ & $1.3 \pm 0.5$ & $1.3 \pm 0.1$ & $1.2 \pm 0.8$ \\
\hline Milking interval per buffalo (h)* & 7 & 7 & 7 & 7 \\
\hline Milking duration (min/milking) ${ }^{\circ}$ & $8.3 \pm 2.3$ & $8.1 \pm 2.5$ & $8.3 \pm 2.5$ & $8.7 \pm 2.1$ \\
\hline Ration & $\mathrm{TMR}^{\#}$ & TMR $^{\#}$ & TMR $^{\#}$ & TMR $^{\#}$ \\
\hline
\end{tabular}

AMS, automatic milking system; TMR, total mixed rotation. *Minimum time between two subsequent milkings; ${ }^{\circ}$ time between buffalo identification and the last teat-cup detachment; "TMR based on corn (18\%) and grass silage (24\%), and was distributed once daily ( 07.30 to $09.00 \mathrm{~h}$ ).

\section{Data selection and analysis}

Before the analysis, data were recollected by consistence and validity. According to Hogeveen et al. (2001), data relative to a milking gap of $<1 \mathrm{~h}$ or $>24 \mathrm{~h}$ were discarded; data relative to a milk yield $<1 \mathrm{~kg}$ were discarded too.

In the first phase of the study 11,972 milking records were analysed. In the second phase of the study data were collected about 270 lactation days, from March 2013 to November 2013 (buffalo lactation's average length) and according to Tangorra et al. (2010) has been established a minimum time of $7 \mathrm{~h}$ between two subsequent milkings.

The R Studio statistical software (version 3.1.1) was used to analyse the collected data. The results obtained from the comparison of the two samples of buffaloes were validated with hypothesis testing for two quantitative variables (milking frequency or daily milk yield) and one factor (type of milking: traditional or AMS). The Student's $t$-test for comparing means of two independent samples was used to determine if the results obtained from the two groups of buffaloes were significantly different or not. The buffaloes were drawn randomly and independently and randomly allocated to the two samples. Each buffalo belonged to only one sample resulting in two independent samples. The collected data as daily milk yield of tandem, milking frequency of AMS and daily milk yield of AMS, followed a normal distribution. While the milking frequency of tandem is not normal, indeed it is constant across the buffaloes (set to 2). Following the methodology suggested by Gosset (1908) we conducted the Student's $t$-test applied setting $\mu_{1}$ equal to 2 , in the tandem distribution of milking frequency. We compare the mean of milking frequency of AMS group $\left(\mu_{2}\right)$ characterised by a normal distribution, to the mean of milking frequency of the tandem group $\left(\mu_{1}\right)$.

In this case, the following $\mathrm{t}$-test statistics has been computed with the null hypothesis statistical hypothesis $\left(\mu_{2}-\mu_{1}=0\right)$ was formulated with unidirectional alternative hypothesis $\left(\mu_{2}>\mu_{1}\right)$ at a significance level $(\alpha)$ of 0.05 .

At this point, as has been evaluated for cows (Erdman and Varner, 1994; De Koning et al., 2002; Wagner-Storch and Palmer, 2003; Wade et al., 2004; Albeni et al., 2005; Speroni et al., 2006; Gygax et al., 2007; Stelwagen et al., 2013; Wright et al., 2013) we want to test the possible correlation between milking frequency of AMS (independent variable) and daily milk yield of AMS (dependent variable) to state if there is an increase in milk yield due to increase of milking frequency. Since the two variables are quantitative and they follow a normal distribution, for this reason, the Pearson product-moment correlation coefficient (r) can be used as measure of correlation, as shown by Hauke and Kossowski (2011). The statistical significance of results was determined using the Student's $t$-test.

\section{Results and discussion}

\section{First phase of the study}

\section{Buffalos' adaptation to automatic milking system}

The adaptation period of buffaloes to robots, evaluated on 11,972 records, was 2 months, during which an increase in the average daily milking frequency for each AMS was observed. Figure 2 is an illustration of the daily milking frequency of the four AMS registered after the adaptation period (from $15^{\text {th }}$ February to $15^{\text {th }}$ March 2009). The result shows that the average milking frequency is $2.3 \pm 0.17$ (times/d) for the four AMS. These values are similar to those found in cows, where the milking frequency mean lies between 2.3 and 2.8 times/d (De Koning and Ouweltjes, 2000; Wendl et al., 2000; Tangorra et al., 2010; Caria et al., 2014). 
In the same reference period (from $15^{\text {th }}$ February to $15^{\text {th }}$ March 2009), mean daily distribution of milkings for four AMS was also monitored. The collected data are reported in Figure 3. The greatest concentration of milkings was noticed during the morning hours between 8.00 and $9.00 \mathrm{~h}$ and in the afternoon from 16.00 to $17.00 \mathrm{~h}$. The animals' routine behaviour was also observed; in particular the one of the multiparous, that spontaneously they went in the AMS to be milked in the same hours during the traditional milking occurred. This behaviour is perhaps due to the short period of using the AMS system.

Figure 4 is a summary of data obtained from the monitoring of the daily distribution of milkings measured a year later (from $15^{\text {th }}$ February to $15^{\text {th }}$ March 2009) the four AMS's settings. The greatest concentration of milking was noticed during the morning, between 6.00 and $9.00 \mathrm{~h}$ and in the afternoon from about 17.00 to $19.00 \mathrm{~h}$. An increase in the milking distribution was observed in the time slots between 2.00 and $7.00 \mathrm{~h}$, and from 9.00 a.m. to $14.00 \mathrm{~h}$, as shown in Figure 4 . After a year of using the AMS, a greater uniformity in the milking distribution during the day was observed. The greatest number of milkings occurs in the early morning hours, in correspondence with the food distribution (TMR), and during the afternoon. Cleaning activities of AMS are randomised across all the hours of the day, so, in Figures 3 and 4, there is no visible effect of the cleaning activities on the availability of AMS for buffaloes. This course is similar to what noticed by various authors (Wendl et al., 2000; Hogeveen et al., 2001; Artmann, 2002; Smith et al., 2002; Wiedemann et al., 2002; Tangorra et al., 2010).

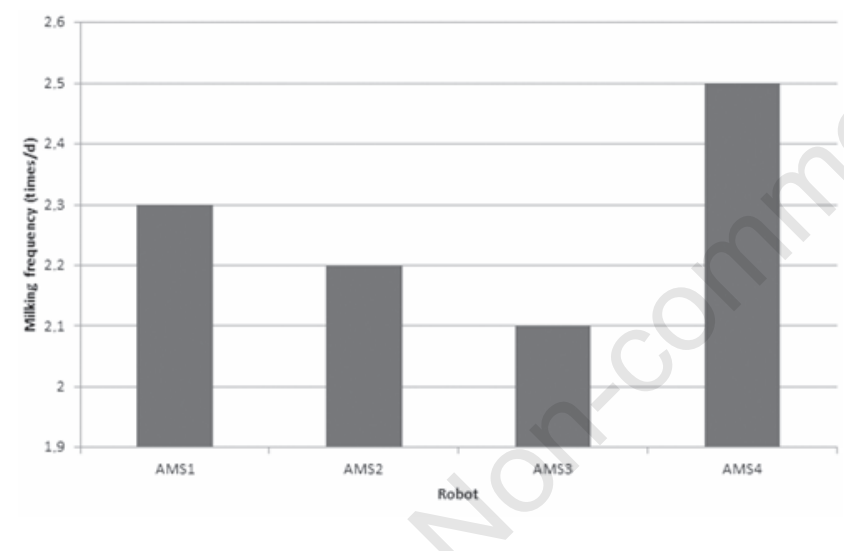

Figure 2. Daily milking frequency of the four robots from $15 / 02 / 2009$ to $15 / 03 / 2009$. AMS, automatic milking system.

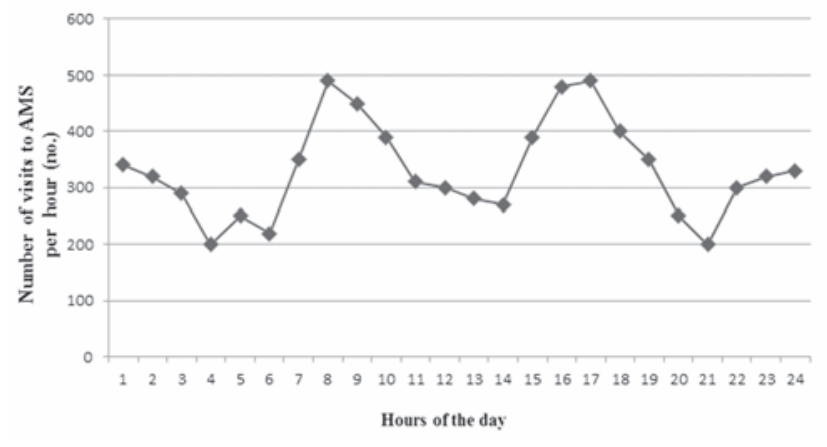

Figure 3. Mean daily distribution of milking for 4 automatic milking systems (AMS) (from 15/02/2009 to 15/03/2009).

\section{Second phase of the study}

\section{Productive aspects and analysis validation}

The second phase of the study, was concerned with the analysis of the productive aspects and was carried out on two groups of buffaloes, each comprising 40 primiparous buffaloes. The first group was transferred to the automatic milking system while the second was subjected to the traditional milking system.

The automatic milking system registered an average of $2.3 \pm 0.17$ milkings per day per buffalo compared to 2 daily milkings per buffalo under the traditional system. The AMS registered an average daily milk yield of $7.9 \pm 1.3 \mathrm{~kg} / \mathrm{d}$ compared to $6.9 \pm 1.06 \mathrm{~kg} / \mathrm{d}$ of the traditional system. Figures 5 and 6 show the production's distributions of 270 lactation days for the two groups of buffaloes milked with AMS system and tandem system respectively. Overall, 15\% of the buffaloes milked in AMS had an average of daily milk yield between 7 and $8 \mathrm{~kg} / \mathrm{d}$ (Figure 5). These results are different from those found for buffaloes milked in the

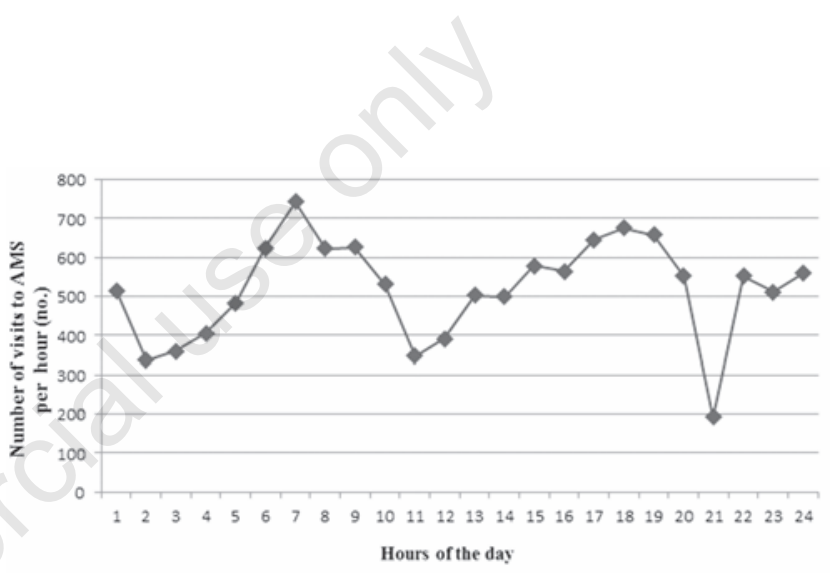

Figure 4. Mean daily distribution of milking for 4 automatic milking systems (AMS) (from 15/02/2010 to 15/03/2010).

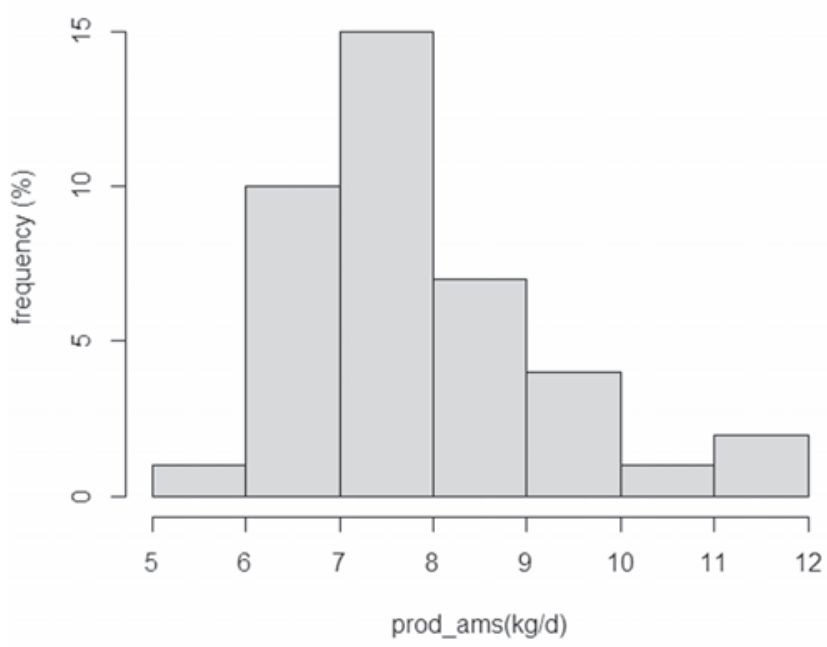

Figure 5. Frequency of daily milk yield into automatic milking system, data collected during 270 days of buffaloes' lactation (during the experimental period March 2013 to November 2013). 
tandem (Figure 6), indeed 10\% of buffaloes had an average of daily milk yield between 6.5 and $7 \mathrm{~kg} / \mathrm{d}$.

Data obtained from the comparison of the two samples of buffaloes were validated with hypothesis testing for two variables. The Student's $t$-test was used to compare and to determine if there was a significant

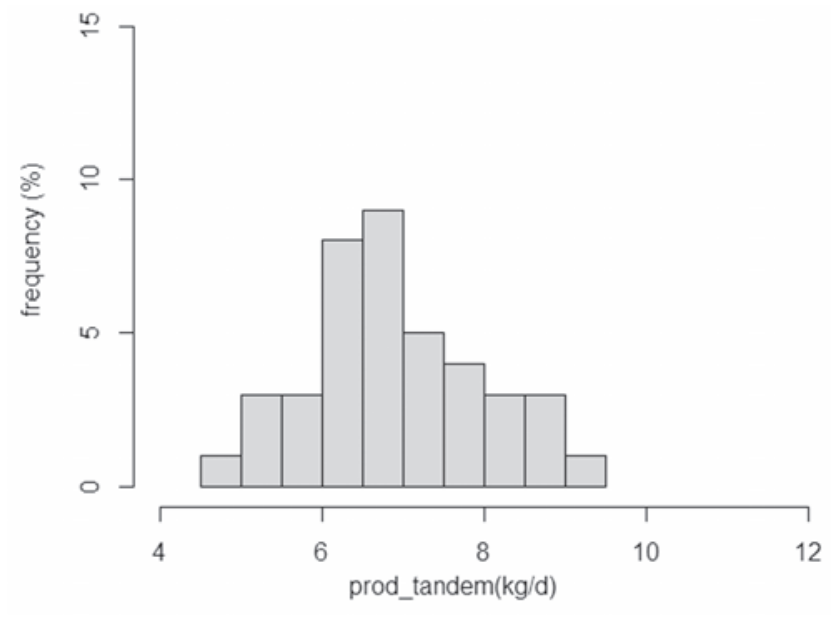

Figure 6. Frequency of daily milk yield into tandem system, data collected during 270 days of buffaloes' lactation (during the experimental period March 2013 to November 2013).

Table 2. Student's $t$-test applied to the average daily milking frequency and daily milk yield, data collected during 270 days of lactation of both buffaloes groups (during the experimental period March 2013 to November 2013).

\begin{tabular}{lcccc}
\hline & \multicolumn{2}{c}{ Tandem } & AMS \\
& Mean & SD & Mean & SD \\
Number of samples & 40 & - & 40 & - \\
Hours from calving (h) & 11.09 & 0.70 & 11.15 & 0.83 \\
\hline Milking grequency (times/d) & 2 & - & $2.3^{* * *}$ & 0.17 \\
Milk yield (kg/d) & 6.9 & 1.06 & $7.9^{* * *}$ & 1.3 \\
\hline Significative level $(\alpha)$ & \multicolumn{5}{c}{0.05} \\
$\mathrm{H}_{0}$ (null hypothesis) ${ }^{\circ}$ & \multicolumn{5}{c}{$\mu_{1}=\mu_{2}$} \\
\hline $\mathrm{H}_{1}$ (alternative hypothesis) & \multicolumn{5}{c}{$\mu_{2}>\mu_{1}$} \\
\hline AMS, automatic milking system; SD, standard deviation. ${ }^{\circ} \mu_{1} ; \mu_{2}$ indicate the population means;
\end{tabular}

Table 3. Pearson product-moment correlation coefficient between milking frequency and average daily milk yield of the 270 lactation days of buffaloes group milked in the automatic milking system (during the experimental period March 2013 to November 2013).

\begin{tabular}{lc} 
Dataset & \\
Number of samples & 40 \\
$r$ & -0.09 \\
\hline$t_{o b s}$ & -0.5708 \\
Significative level $(\alpha)$ & 0.05 \\
\hline $\mathrm{H}_{0}$ (null hypothesis) & $\beta=0$ \\
$\mathrm{H}_{1}$ (alternative hypothesis) & $\beta \neq 0$ \\
\hline P-value & 0.57 \\
\hline
\end{tabular}

difference between the means of the two independent samples. Table 2 shows the results obtained from the test applied to the average daily milking frequency of two samples of buffaloes. Since the P-value was less than $0.05(\mathrm{P}=6.605 \mathrm{E}-14)$, it was concluded that the mean difference observed between the two groups is significant and therefore the increase in the average daily milking frequency can be attributed to the use of the AMS if other factors are fixed. This result is similar to those reported for milking cows by De Koning and Ouweltjes (2000), Wendl et al. (2000), Tangorra et al. (2010) and Caria et al. (2014).

Table 2 also shows the results obtained from the $t$-test applied to the average daily milk yield of the two samples of buffaloes. Since the Pvalue was less than $0.05(\mathrm{P}=2.2 \mathrm{E}-16)$ the mean difference observed between the two groups is significant and therefore the $12 \%$ increasing in the average daily milk yield can be attributed to the use of the AMS if other factors, like feeding, are fixed as noticed for milking cows by De Koning et al. (2002), Wagner-Storch and Palmer (2003), Wade et al. (2004) and Caria et al. (2014).

Table 3 reports the result of Pearson product-moment correlation coefficient $(r)$. Since the p-value was greater than $0.05(P=0.57)$ the null hypothesis is accepted and therefore there is not a significant relationship between the daily milking frequency and daily production. These results are in agreement with those for dairy cattle reported by Erdman and Varner (1994), Albeni et al. (2005), Speroni et al. (2006) and Gygax et al. (2007). The increase of average daily milk yield with AMS compared to traditional milking could be explained either with a less physiological stress of buffalo during AMS milking as it observed with cows (Hopster et al., 2002) and also, as already done by Knight and Wilde (1993) and Løvendahl and Madsen (2001) for cows, with a more constant production mostly during the final phase of lactation.

\section{Conclusions}

This study shows that the use of AMS is suitable for dairy buffaloes farms. In fact, buffaloes found rapid adaptation to AMS. The daily milkings distribution is similar to those reported in literature, for cows and buffaloes, by other authors. The statistical analysis, as expected, shows an increase of milking frequency in AMS and an increase of daily milk yield in AMS. Those results are in agreement to results previously stated in bibliographic.

\section{References}

Albeni F., Degano L., Calza F., Giangiacomo R., Pirlo G. 2005. Milk quality and automatic milking: fat globule size, natural creaming, and lypolysis. J. Dairy Sci. 88:3519-29.

Ambord S., Stoffel M.H., Bruckmaier R.M. 2010. Teat anatomy affects requirements for udder preparation in Mediterranean buffaloes. J. Dairy Res. 77:468-73.

Amos H.E., Kiser T., Loewenstein M. 1985. Influence of milking frequency on productive and reproductive efficiencies of dairy cows. J. Dairy Sci. 68:732-9.

Artmann R. 2002. Practical experiences with automatic milking systems in larger farms. pp 107-110 in $1^{\text {st }}$ North American Conference on Robotic Milking, Toronto, Canada.

Bijl R., Kooistra S.R., Hogeveen H. 2007. The profitability of automatic milking on Dutch dairy farms. J. Dairy Sci. 90:239-48.

Borghese A., Rasmussen M., Thomas C.S. 2007. Milking management of dairy buffaloes. Ital. J. Anim. Sci. 6:39-50.

Caria M., Tangorra F.M., Leonardi S., Bronzo V., Murgia L., Pazzona A. 
2014. Evaluation of the performance of the first automatic milking system for buffaloes. J. Dairy Sci. 97:1491-8.

De Koning C.J.A.M. 2010. Automatic milking-common practice on dairy farms. pp 52-67 in Proc. $1^{\text {th }}$ North American Conference on Precision Dairy Management and The Second North American Conference on Robotic Milking, Toronto, Canada.

De Koning K., Ouweltjes W. 2000. Maximising the milking capacity of an automatic milking system. pp 38-46 in Proc. Int. Symp. Robotic Milking, Lelystad, the Netherlands. Wageningen Academic Publ., Wageningen, the Netherlands.

De Koning K., van der Vost Y., Meijering A. 2002. Automatic milking experience and development in Europe. pp I1-I11 in Proc. $1^{\text {st }}$ North Am. Conf. Robotic Milking, Toronto, Canada. Wageningen Academic Publ., Wageningen, the Netherlands.

Erdman R.A., Varener M. 1994. Fixed yield responses to increased milking frequency. J. Dairy Sci. 78:1199-203.

Faugno S., Infascelli R., Boccia L. 2009. Applicazione di un sistema di mungitura robotizzata alla bufala. pp 7-49 in IX Convegno Nazionale dell'Associazione Italiana di Ingegneria Agraria, Ischia Porto, Italy.

Gosset W.S. 1908. The probable error of a mean. Biometrika 6:1-25.

Gygax L., Neuffer I., Kaufmann C., Hauser R., Wechsler B. 2007. Milk cortisol concentration in automatic milking systems compared with auto-tandem milking parlors. J. Dairy Sci. 89:3447-54.

Hauke J., Kossowski T. 2011. Comparison of values of Pearson's and Spearman's correlation coefficients on the same sets of data. Quest. Geogr. 30:2.

Hogeveen H., Ouweltjes W., De Koning C.J.A.M., Stelwagen K. 2001. Milking interval, milk production and milk flow-rate in an automatic milking system. Livest. Prod. Sci. 72:157-67.

Hopster H., Bruckmaier R.M., van der Werf J.T.N., Korte S.M., Macuhova J., Korte-Bouws G., Cvan Reenen G. 2002. Stress responses during milking: comparing conventional and automatic milking in primiparous dairy cows. J. Dairy Sci.85:3206-16.

Infascelli R., Faugno S., Pindozzi S., Pelorosso R., Boccia L. 2010. The environmental impact of buffalo manure in areas specialized in mozzarella production, southern Italy. Geospatial Health 5:131-7.

Jacobs J.A., Siegford J.M. 2012. Invited review: The impact of automatic milking systems on dairy cow management, behavior, health, and welfare. J. Dairy Sci. 95:2227-47.

Knight C.H., Wilde C.J. 1993. Mammary cell changes during pregnancy and lactation. Livest. Prod. Sci., 35:3-19.

Løvendahl P., Madsen P. 2001. Does automatic milking change the shape of the lactation curve and composition of milk?
52 ${ }^{\text {nd }}$ EAAP Meeting, Budapest, Hungary.

Pindozzi S., Faugno S., Okello C., Boccia L. 2013. Measurement and prediction of buffalo manure evaporation in the farmyard to improve farm management. Biosyst. Engine. 115:117-24.

Smith J.W., Ely L.O., Graves W. M., Gilson W.D. 2002. Effect of milking frequency on DHI performance measures. J. Dairy Sci. 85:3526-33.

Speroni M., Pirlo G., Lolli S. 2006. Effect of automatic milking systems on milk yield in a hot environment. J. Dairy Sci. 89:4687-93.

Stelwagen K., Phyn C.V, Davis S.R., Guinard-Flament J., Pomiès D., Roche J.R., Kay J.K. 2013. Invited review: reduced milking frequency: milk production and management implications. J. Dairy Sci. 96:3401-13.

Svennersten-Sjaunja K.M., Pettersson G. 2008. Pros and cons of automatic milking in Europe. J. Anim. Sci. 86:37-46.

Tangorra F.M., Pazzona A., Murgia L., Moroni P., Leonardi S., Caria M., Bronzo V. 2010. Robotic milking of buffaloes: a preliminary survey on milking capacity of automatic milking systems. In $1^{\text {st }}$ North American Conference on Precision Dairy Management, Toronto, Canada.

Thomas C.S. 2004. Milking management of dairy buffaloes. PhD Thesis. Department of Animal Nutrition and Management, Swedish University of Agricultural Sciences, Uppsala, Sweden.

Wade K.M., van Asseldonk M.A.P.M., Berentsen P.B.M., Ouweltjes W., Hogeveen H. 2004. Economic efficiency of automatic milking systems with specific emphasis on increases in milk production. In: A. Meijering, H. Hogeveen, and C.J.A.M. De Koning (eds.), Automatic milking: a better understanding. Wageningen Academic Publ., Wageningen, the Netherlands, pp 62-67.

Wagner-Storch A.M., Palmer R.W. 2003. Feeding behavior, milking behavior, and milk yields of cows milked in a parlor versus automatic milking system. J. Dairy Sci. 86:1494-502.

Wendl G., Harms J., Schön H. 2000. Analysis of milking behavior on automatic milking. In: H. Hogeveen and A. Meijering (ed.), Proc. Int. Symp. Robotic Milking, Lelystad, the Netherlands. Wageningen Academic Publ., Wageningen, the Netherlands, pp 143-151.

Wiedemann M., Wendl G., Schön H. 2002. Effects of energy and protein content in basic feed on milking and cow behaviour in automatic milking systems. pp 93-96 in $1^{\text {st }}$ North American Conference on Robotic Milking, Toronto, Canada.

Wright J.B., Wall E.H., McFadden T.B. 2013. Effects of increased milking frequency during early lactation on milk yield and udder health of primiparous Holstein heifers. J. Anim. Sci. 91:195-202.

Zicarelli L. 2001. La Bufala Mediterranea Italiana: esempio di una razza autoctona in espansione. Sci. Tecn. Lattiero Casearia. 52:279-84. 